\title{
Water Quality Parameter Analysis for the Feasibility of Shrimp Culture in Takalar Regency, Indonesia
}

Muhammad Kasnir ${ }^{1 *}$, Harlina ${ }^{1}$ and Rosmiati ${ }^{2}$

${ }^{1}$ Faculty of Marine Science and Fisheries, Indonesia Moeslim University, Makassar

${ }^{2}$ Research Institute for Coastal Aquaculture, Maros, South Sulawesi

\begin{abstract}
The physicochemical studies were carried out to asses water resource in Mangara Bombang District, South Sulawesi in relation to their potential for shrimp aquaculture use. Water samples were collected from pond, coastal area and river and analyzed for $\mathrm{pH}, \mathrm{TSS}$, salinity, dissolved oxygen (DO), biodegradable organic matter (BOD), Ammonia $\left(\mathrm{NH}_{3}-\mathrm{N}\right)$, Nitrate $\left(\mathrm{NO}_{2}-\mathrm{N}\right)$, Nitrite $\left(\mathrm{NO}_{3}-\mathrm{N}\right)$, and Orthophosphate $\left(\mathrm{PO}_{4}-\mathrm{P}\right)$. The results revealed that Mangara Bombang District is suitable for the development of pond shrimp farm with values obtained for $\mathrm{pH}$, Temperature, TSS, salinity, dissolved oxygen (DO), biodegradable organic matter $(B O D)$, Ammonia $\left(\mathrm{NH}_{3}-\mathrm{N}\right)$, Nitrate $\left(\mathrm{NO}_{2}-\mathrm{N}\right)$, Nitrite $\left(\mathrm{NO}_{3}-\mathrm{N}\right)$, and orthophosphate $\left(\mathrm{PO}_{4}{ }^{3}-\mathrm{P}\right)$ were $8.17 \pm 0.38,29.56 \pm 0.75^{\circ} \mathrm{C}, 37.73 \pm 12.44 \mathrm{mg} / \mathrm{l}, 30.01 \pm 3.77,17$, $5.89-6.02 \mathrm{mg} / \mathrm{l}, 1.16 \pm 0.53 \mathrm{mg} / \mathrm{l}, 0.02614 \pm 0.3355 \mathrm{mg} / \mathrm{l}, 0.0115 \pm 0.0104 \mathrm{mg} / \mathrm{l}, 0.0555 \pm 0.0956 \mathrm{mg} / \mathrm{l}$, and $0.0201 \pm$ 0.0051 , respectively for pond water source, $8.06 \pm 0.40,28.56 \pm 2.72^{\circ} \mathrm{C}, 58.17 \pm 22.18 \mathrm{mg} / \mathrm{l}, 30.90 \pm 4.01^{\circ} / 00,5.88$ $\pm 1.42 \mathrm{mg} / \mathrm{l}, 0.74 \pm 0.27 \mathrm{mg} / \mathrm{l}, 0.2636 \pm 0.3303,0.0110 \pm 0.0141 \mathrm{mg} / \mathrm{l}, 0.2483 \pm 0.5690 \mathrm{mg} / \mathrm{l}$, and $0.0583 \pm 0.0648$, respectively for the coastal water source, and $7.77 \pm 0.42,26.77 \pm 19.94^{\circ} \mathrm{C}, 60.13 \pm 15.45 \mathrm{mg} / \mathrm{l}, 17.95 \pm 3.79 \%$, $6.02 \pm 0.86,1.32 \pm 0.80 \mathrm{mg} / \mathrm{l}, 0.1101 \pm 0.0812 \mathrm{mg} / \mathrm{l}, 0.0924 \pm 0.1241 \mathrm{mg} / \mathrm{l}, 0.0250 \pm 0.0074 \mathrm{mg} / \mathrm{l}$, and $0.0051 \pm$ $0.0037 \mathrm{mg} / \mathrm{l}$, respectively for river water source.
\end{abstract}

Keywords: Aquaculture; Water quality; Feasibility

\section{Introduction}

Tiger shrimp production in South Sulawesi amounted to about 12599.50 tons in 2007. Nationally, its production was at the fourth ranking after Riau Islands, North Sumatra and West Java [1]. The tiger shrimp production number was the aggregates production in several Regencies which have the coastal area in South Sulawesi Province. One of them is Takalar Regency particularly, in Mangara Bombang District. The potential of culture fishery which can be developed in coastal area of Mangara Bombang is shrimp culture in ponds. Shrimp culture in ponds has been expanded to be a bio-food industry proved to yield foreign exchange and provide job opportunities besides animal protein source. The existence of a wide market support, stable price, technology support in the production process, commercial akuinput, the potential land availability, and the Government's policy support has led to shrimp commodity to continually grow being the excellent fishery and continue to be developed as the excellent commodity to increase foreign exchange [2-4]. Nevertheless, the sustainability pond aquaculture in highly is depended on the dynamic aspects of coastal environment quality as a result of any interaction among users in the coastal area besides pond aquaculture activity itself.

Mangara Bombang is one of Districts located in coastal area of Takalar Regency which has a developed aquaculture potential. Therefore, it has been selected as one of the aquaculture development area centers by the Government of Takalar Regency. Seaweed and shrimp aquaculture have been the aquaculture activities developed in the current time in this District. The whole pond wide in the coastal area of Mangara Bombang is 863.097 ha. From that, there has been 35.98 ha and 827.117 ha managed by using an intensive technology and traditional intensive, respectively [5].

Government's Takalar through its Marine and Fishery Service in 2008 arranged aquaculture development program plans and one of them is the pond aquaculture development. Special in Mangara Bombang District, 1851 ha and 335 ha of its coastal area have been used for shrimp monoculture and shrimp-fish milk polyculture development with a production target of 2696.13 tons and 125.10 tons, respectively [5].

The pond shrimp culture activity in the coastal area of Mangara Bombang District in this current time and its development to the future will result in damages on the aquatic environment in someday if there is no any good management. The existence of damaged aquatic environment will finally threaten the sustainability of pond shrimp culture fishery resource. Therefore, this study aims to determine the water quality condition for the sustainability of pond shrimp culture in the coastal area of Mangara Bombang District. This study is expected to give the information to pond shrimp farmers to increase their production. In addition, the data obtained can be used as the supporting data in the formulating of Government's policies for the planning and managing of shrimp pond area.

\section{Research Methods}

\section{Location and research time}

This study was done in a shrimp farm area in the coastal area of Mangara Bombang District, Takalar Regency, South Sulawesi, Indonesia started from June 2010 to July 2010.

\section{Research method}

The collection of biophysical data and waters quality was consisted

*Corresponding author: Muhammad Kasnir, Faculty of Marine Science and Fisheries, Indonesia Moeslim University, Makassar, Tel: 94 (0) 41 2227026; E-mail: Kasnir_umi@yahoo.co.id

Received May 20, 2014; Accepted September 25, 2014; Published October 02 2014

Citation: Kasnir M, Harlina, Rosmiati (2014) Water Quality Parameter Analysis for the Feasibility of Shrimp Culture in Takalar Regency, Indonesia. J Aquac Res Development 5: 273. doi:10.4172/2155-9546.1000273

Copyright: (C) 2014 Kasnir M, et al. This is an open-access article distributed under the terms of the Creative Commons Attribution License, which permits unrestricted use, distribution, and reproduction in any medium, provided the original author and source are credited. 
of pond soil quality, water quality, oceanography (tide, current speed and depth), shrimp farm sediment quality, and coastal waters base land subsrate data. Pond soil quality data was collected from 10 stations in several pond compartments. Meanwhile, for the coastal waters water quality data was collected from 6 stations consisted of 2 stations of river, 2 stations of pond and 2 stations of outlets. Moreover, shrimp farm sediment quality and coastal waters base substrate quality data were collected from 2 stations and 13 sampling points, respectively.

\section{Data and data source}

Primery and secondary data were used in this study. Primery data was collected through observation and direct interview in the research location whilst, secondary data was obtained through the searching of various refferences to the several Agencies of Goverment and non Goverment that are related to this study. Several water quality parameters as listed in Table 1 which were the important parameters in the shrimp aquaculture success. The monitoring and sample collection of water quality were directly carried out (in situ). Water quality analysis was directly done in the field and laboratory and the results can be seen in Table 1 .

\section{Results and Discussions}

Water quality is one of the important factors in the determination of shrimp farm culture activity success. The result "analysis of the water quality in several stations of river and coastal was shown in Tables 2 and 3.

Source : Boyd, Poernomo, Widigdo, Soewardi, and Environment Ministry (2004) From the Tables 2 and 3, it can be explained as followed:

\section{Waters temperature}

The temperature measurement of traditional shrimp farm

\begin{tabular}{|c|l|c|c|}
\hline No & Water quality parameter & Equipment/Method & Note \\
\hline 1 & Temperature & YSI & Insitu \\
2 & Kekeruhan & Turbidimeter & Insitu \\
3 & Total suspended solid (TSS) & Gravimetri & Laboratory \\
4 & pH & YSI & Insitu \\
5 & Salinity & $\mathrm{YSI}$ & Insitu \\
6 & Dissolved oxygen & YSI & Insitu \\
7 & Ammonia( $\left.\mathrm{NH}_{3}-\mathrm{N}\right)$ & Spectrophotometer & Laboratory \\
8 & Nitrate $\left(\mathrm{NO}_{2}-\mathrm{N}\right)$ & Spectrophotometer & Laboratory \\
9 & Nitrite $\left(\mathrm{NO}_{3}-\mathrm{N}\right)$ & Spectrophotometer & Laboratory \\
10 & Orthoposphate $\left.\mathrm{PO}_{4}-\mathrm{P}\right)$ & Spectrophotometer & Laboratory \\
11 & BOD & Titrimetric & Laboratory \\
\hline
\end{tabular}

Table 1: Water quality parameters observed

\begin{tabular}{|c|c|c|c|}
\hline \multirow{2}{*}{$\begin{array}{l}\text { Water quality } \\
\text { parameter }\end{array}$} & \multicolumn{2}{|c|}{ Location/Measurement station } & \multirow[t]{2}{*}{ Tolerance value } \\
\hline & River & Coastal & \\
\hline Temperature $\left({ }^{\circ} \mathrm{C}\right)$ & $26.77 \pm 17.94$ & $28.56 \pm 2.72$ & $20-32$ \\
\hline Salinity (o/oo) & $17.95 \pm 3.79$ & $30.90 \pm 4.01$ & $5-34$ \\
\hline $\mathrm{DO}(\mathrm{mg} / \mathrm{l})$ & $6.02 \pm 0.86$ & $5.89 \pm 1.41$ & $\geq 3$ \\
\hline $\mathrm{pH}$ & $7.77 \pm 0.42$ & $8.06 \pm 0.40$ & $6.5-8.5$ \\
\hline $\mathrm{BOD}_{5}(\mathrm{mg} / \mathrm{l})$ & $1.32 \pm 0.80$ & $0.74 \pm 0.27$ & $<25$ \\
\hline TSS (mg/l) & $60.44 \pm 9.35$ & $58.17 \pm 22.18$ & $25-80$ \\
\hline BOT (mg/l) & $26.04 \pm 5.73$ & $18.77 \pm 5.64$ & - \\
\hline Turbidity (NTU) & $21.41 \pm 4.41$ & $14.42 \pm 17.63$ & $\leq 30$ \\
\hline $\mathrm{NH}_{3}-\mathrm{N}(\mathrm{mg} / \mathrm{l})$ & $0.1101 \pm 0.0812$ & $0.2636 \pm 0.3303$ & $\leq 1.0$ \\
\hline $\mathrm{NO}_{2}-\mathrm{N}(\mathrm{mg} / \mathrm{l})$ & $0.0251 \pm 0.0073$ & $0.2483 \pm 0.5690$ & 0.25 \\
\hline $\mathrm{NO}_{3}-\mathrm{N}(\mathrm{mg} / \mathrm{l})$ & $0.0924 \pm 0.1241$ & $0.0111 \pm 0.0140$ & - \\
\hline $\mathrm{PO}_{4}-\mathrm{P}(\mathrm{mg} / \mathrm{l})$ & $0.0053 \pm 0.0036$ & $0.0582 \pm 0.0647$ & $0.05-0.50$ \\
\hline
\end{tabular}

Table 2: Analysis data of water quality parameters measurement in several stations of river and coastal.

\begin{tabular}{|c|c|c|c|}
\hline \multirow{2}{*}{$\begin{array}{l}\text { Water quality } \\
\text { parameter }\end{array}$} & \multicolumn{2}{|c|}{ Location/Measurement Station } & \multirow[t]{2}{*}{ Tolerance value } \\
\hline & In farm & Outlet & \\
\hline Temperature $\left({ }^{\circ} \mathrm{C}\right)$ & $29.56 \pm 0.75$ & $30.00 \pm 2,03$ & $20-32$ \\
\hline Salinity (o/oo) & $31.46 \pm 1.37$ & $31.03 \pm 6,64$ & $5-34$ \\
\hline $\mathrm{DO}(\mathrm{mg} / \mathrm{l})$ & $6.65 \pm 1.08$ & $4.41 \pm 0.53$ & $\geq 3$ \\
\hline $\mathrm{pH}$ & $8.17 \pm 0.38$ & $8.06 \pm 0.42$ & $6.5-8.5$ \\
\hline $\mathrm{BOD}_{5}(\mathrm{mg} / \mathrm{l})$ & $1.16 \pm 0.53$ & $1.07 \pm 0.51$ & $<25$ \\
\hline TSS (mg/l) & $37.73 \pm 12.44$ & $55.20 \pm 10.54$ & $25-80$ \\
\hline BOT (mg/l) & $22.83 \pm 12.47$ & $25.13 \pm 6.92$ & - \\
\hline Turbidity (NTU) & $9.64 \pm 3.43$ & $19.23 \pm 2.80$ & $\leq 30$ \\
\hline $\mathrm{NH}_{3}-\mathrm{N}(\mathrm{mg} / \mathrm{l})$ & $0.2614 \pm 0.3355$ & $0.0982 \pm 0.0033$ & $\leq 1.0$ \\
\hline $\mathrm{NO}_{2}-\mathrm{N}(\mathrm{mg} / \mathrm{l})$ & $0.0555 \pm 0.0956$ & $0.1021 \pm 0.1493$ & 0.25 \\
\hline $\mathrm{NO}_{3}-\mathrm{N}(\mathrm{mg} / \mathrm{l})$ & $0.0115 \pm 0.0104$ & $0.0023 \pm 0.0003$ & - \\
\hline $\mathrm{PO}_{4}-\mathrm{P}(\mathrm{mg} / \mathrm{l})$ & $0.0201 \pm 0.0051$ & $0.0422 \pm 0.0273$ & $0.05-0.50$ \\
\hline
\end{tabular}

Table 3: Analysis data of water quality parameters measurement in several stations of shrimp farm and outlet.

waters was obtained the temperature of $29.56 \pm 0.75^{\circ} \mathrm{C}$. Meanwhile, temperature of pond waters found of temperature measurement result in the coastal waters and river was $28.56 \pm 2.72^{\circ} \mathrm{C}$ and $26.77 \pm$ $19.94^{\circ} \mathrm{C}$, respectively. The temperatures observed were still suitable for shrimp culture. As reported by Boyd, Poernomo, Widigdo, Soewardi Temperature with range from $20-32^{\circ} \mathrm{C}$ was temperature values recommended for shrimp culture and $29-30^{\circ} \mathrm{C}$ were the optimum temperature for cultured shrimp growth.

\section{Salinity}

The salinity measurement result showed that the salinity obtained in the river and coastal waters was still in the values recommended namely $17.95 \pm 3.79 \%$ oo and $30.90 \pm 4.01 \%$, respectively. Boyd, Poernomo, Widigdo, Soewardi recommended that Salinity of 5-35\% are suitable for shrimp culture and the salinity of $15-25 \%$ oo are salinity suggested for the optimum growth of shrimp.

\section{pH}

The shrimp waters $\mathrm{pH}$ measurement result for 24 hours was 8.17 \pm 0.38 . $\mathrm{pH}$ of pond waters obtained was range from 8.06-8.17 with the highest $\mathrm{pH}(8.17)$ at $12.00-13.00$ and the lowest at 01.30 and 03.30 04.00. $\mathrm{pH}$ measurement result in the river and coastal waters was 7.77 \pm 0.42 and $8.06 \pm 0.40$, respectively. These $\mathrm{pH}$ values were still in the range of $\mathrm{pH}$ which is suitable for shrimp culture namely 6.5-8.5 with the optimum $\mathrm{pH}$ of 8.0-8.5 [6-9].

\section{Dissolved oxygen}

Maintenance of an adequate level of DO in pond water is very important for shrimp survival and prolonged exposure to the stress of low concentration of oxygen can inhibit shrimp growth. DO concentration in this study was considered normal and acceptable for a shrimp pond. Over the observation period, mean dissolved oxygen concentrations found in the waters was $6.65 \pm 1.08 \mathrm{mg} / \mathrm{l}$. Meanwhile, dissolved oxygen concentrations in shrimp farm for 24 hours of the observation ranged from 5.89-6.02 $\mathrm{mg} / \mathrm{l}$ with the highest dissolved oxygen $(6.02 \mathrm{mg} / \mathrm{l})$ at 12.00 and the lowest $(5.89 \mathrm{mg} / \mathrm{l})$ at 20.00 . In addition, mean dissolved oxygen concentration in the river and coastal waters was $6.02 \pm 0.86$ and $5.88 \pm 1.42 \mathrm{mg} / \mathrm{l}$, respectively. These values are still suitable for shrimp culture as reported by Boyd, Poernomo , Widigdo, the tolerance dissolved oxygen for shrimp culture is $\geq 3 \mathrm{mg} / \mathrm{l}$ (3-10 mg/l) and the optimum dissolved oxygen ranges from $4-7 \mathrm{mg} / \mathrm{l}$. Cheng et al., [10] reported that DO values higher than $5 \mathrm{mg} / \mathrm{l}$ have often been recommended for intensive culture practices. 
Citation: Kasnir M, Harlina, Rosmiati (2014) Water Quality Parameter Analysis for the Feasibility of Shrimp Culture in Takalar Regency, Indonesia. J Aquac Res Development 5: 273. doi:10.4172/2155-9546.1000273

Page 3 of 3

\section{Total Suspended Solid (TSS)}

Total suspended solid (TSS) measurement result exhibited that TSS value in shrimp farm was $37.73 \pm 12.44 \mathrm{mg} / \mathrm{l}$ whilst, TSS value in outlet of traditional shrimp farm was $55.20 \pm 10.54 \mathrm{mg} / \mathrm{l}$. Moreover, this value for coastal waters and river was $58.17 \pm 22.18 \mathrm{mg} / \mathrm{l}$ and $60.13 \pm 15.45$ $\mathrm{mg} / \mathrm{l}$, respectively. These TSS content were still in the tolerance limit for shrimp pond culture according to the tolerance value reported by Widigdo, Environment Ministry for shrimp farm namely $25-80 \mathrm{mg} / \mathrm{l}$.

\section{Biochemical Oxygen Demand/BOD}

Biochemical Oxygen Demand $\left(\mathrm{BOD}_{5}\right)$ measurement obtained $\mathrm{BOD}_{5}$ value was $1.16 \pm 0.53 \mathrm{mg} / \mathrm{l}$ whilst, the $\mathrm{BOD}_{5}$ value for coastal waters and river was $0.74 \pm 0.27 \mathrm{mg} / \mathrm{l}$ and $1.32 \pm 0.80 \mathrm{mg} / \mathrm{l}$, respectively. These $\mathrm{BOD}_{5}$ values are still suitable for shrimp culture based on the $\mathrm{BOD}_{5}$ value recommended by Environment Ministry (2004) namely $<25 \mathrm{mg} / \mathrm{l}$. According to the pollution level, coastal waters of Mangara Bombang District is in unpolluted waters category indicating that it is suitable for shrimp culture.

\section{Ammonia $\left(\mathrm{NH}_{3}-\mathrm{N}\right)$}

Ammonia $\left(\mathrm{NH}_{3}-\mathrm{N}\right)$ content observed in shrimp farm waters was $0.02614 \pm 0.3355 \mathrm{mg} / \mathrm{l}$. Meanwhile, ammoniac $\left(\mathrm{NH}_{3}-\mathrm{N}\right)$ content obtained in coastal waters and river was $0.2636 \pm 0.3303 \mathrm{mg} / \mathrm{l}$ and $0.1101 \pm 0.0812 \mathrm{mg} / \mathrm{l}$, respectively. These ammonia contents found are still in the save limit for shrimp culture based on the ammonia $\left(\mathrm{NH}_{3}-\mathrm{N}\right)$ content suggested by Boyd, Poernomo, Widigdo, Environment Ministry namely $<1.0 \mathrm{mg} / \mathrm{l}$.

\section{Nitrite $\left(\mathrm{NO}_{2}\right)$}

Nitrite $\left(\mathrm{NO}_{2}\right)$ content observed in shrimp farm waters was $0.0555 \pm$ $0.0956 \mathrm{mg} / \mathrm{l}$ whilst, nitrite $\left(\mathrm{NO}_{2}-\mathrm{N}\right)$ content in coastal waters and rivers was $0.2483 \pm 0.5690 \mathrm{mg} / \mathrm{l}$ and $0.0250 \pm 0.0074 \mathrm{mg} / \mathrm{l}$, respectively. These values are still in the save limit for shrimp farm based on the tolerance value recommended for shrimp culture namely $<0.25 \mathrm{mg} / 1$ [11-14].

\section{Nitrate $\left(\mathrm{NO}_{3}-\mathrm{N}\right)$}

Nitrate $\left(\mathrm{NO}_{3}-\mathrm{N}\right)$ content in shrimp farm waters was $0.0115 \pm$ $0.0104 \mathrm{mg} / \mathrm{l}$. Meanwhile, Nitrate $\left(\mathrm{NO}_{3}-\mathrm{N}\right)$ content in the coastal waters and river was $0.0110 \pm 0.0141 \mathrm{mg} / \mathrm{l}$ and $0.0924 \pm 0.1241 \mathrm{mg} / \mathrm{l}$, respectively. Nitrate $\left(\mathrm{NO}_{3}-\mathrm{N}\right)$ content obtained also indicates that Mangara Bombang is suitable for shrimp culture.

\section{Orthophosphate $\left(\mathrm{PO}_{4}^{3--} \mathrm{P}\right)$}

Phosphate $\left(\mathrm{PO}_{4}-\mathrm{P}\right)$ content obtained in the shrimp pond waters, coastal waters and river was still in the recommended value limit for shrimp culture activity namely; $0.0201 \pm 0.0051,0.0583 \pm 0.0648$ and $0.0051 \pm 0.0037 \mathrm{mg} / \mathrm{l}$, respectively. As reported by Boyd; Poernomo; Widigdo; Environment Ministry, the value limit of Phosphate $\left(\mathrm{PO}_{4}-\mathrm{P}\right)$ content which is suitable for shrimp culture activity is $0.05-0.5 \mathrm{mg} / \mathrm{l}$.

\section{Turbidity}

The turbidity value observed in the shrimp pond was $9.69 \pm 3.41$ NTU whilst, that obtained in the coastal waters and river was 14.44 $\pm 17.65 \mathrm{NTU}$ and $21.42 \pm 4.43$, respectively. These turbidity values were still in the tolerance limit for shrimp farm culture. In general, the water quality in the coastal area of Mangara Bombang District is suitable or supporting for shrimp farm culture activity based on the criteria recommended by Boyd, Poernomo, Widigdo, Soewardi and Environment Ministry.

\section{Conclusion and Suggestion}

\section{Conclusion}

The study has provided the information about the water quality status of Mangara Bombang District and its suitability for pond shrimp farm. The field and laboratory observations on the water quality revealed that the study area have high potential for pond shrimp culture development based on values obtained which were in conformity with recommended values for shrimp culture,

\section{Suggestion}

It is suggested to further study on the water quality feasibility for the development of shrimp culture for intensive and semi intensive culture technology so it can be obtained the picture of water quality feasibility for shrimp culture development in the various culture technology.

\section{References}

1. Marine and Fisheries Service of South Sulawesi Province (2007) Annual Report of Marine and Fisheries Service.

2. Cholik F, Anwar ZI, Sutartamat T (1998) The healthy shrimp embankment Centre for Research and development of coastal fishery-JICA. Bali.

3. Kusumastanto (2003) Ocean policy in the development of maritime nation in regional autonomy.

4. Widigdo B (2002) The development and function of culture fisheries in the construction.

5. Marine and Fisheries Service of Takalar Regency (2008) Program plan for culture fisheries development in the coastal area of Takalar Regency.

6. Poernomo A (1992) The selection of environment friendly shrimp pond. Centre for Research and development of fisheries,. Jakarta.

7. Widigdo B, Kadarwan S (2002) Criteria formulation of ecobiological to determine the natural potential of the coastal area for pond culture.

8. Soewardi K. (2002) Pond water quality management.

9. Environment Ministry (2004) Environment Ministry Decision No.51 in 2004 about sea water quality standard, Jakarta.

10. Cheng W, Liu CH, Kuo CM (2003) Effects of dissolved oxygen on hemolymph parameters of freshwater giant prawn, Macrobrachium rosenbergii (de Man). Aquaculture 220: 843-856.

11. Boyd CE (1990) Water quality in ponds for aquaculture. Alabama Agricultura Experiment Station. Auburn University, Alabama.

12. Soewardi K (2007) The continuous pond culture management.

13. Marine and Fisheries Service of Takalar Regency (2008) Annual Report of Marine and Fisheries Service of Takalar Regency.

14. Boyd CE (1998) Pond water aerations systems. Journal of Aquaculture Engineering 18: 9-20. 